\title{
EFEK ANTIMIKROBA EKSTRAK ETANOL DAUN PEPAYA (CARICA PAPAYA L) TERHADAP SHIGELLA DYSENTERIAE SECARA IN VITRO DENGAN METODE DILUSI TABUNG DAN DILUSI AGAR
}

\author{
Senja Ristya Hertanti ${ }^{1}$, Irma Suswati ${ }^{2}$, Indra Setiawan ${ }^{3}$
}

Fakultas Kedokteran, Univesitas Muhammadiyah Malang, J1. Bendungan Sutami No. 188, Malang, 65114, Indonesia, +62 341582060

\begin{abstract}
ABSTRAK
Efek Antimikroba Ekstrak Etanol Daun Pepaya (Carica papaya, L.) terhadap Shigella dysenteriae secara In Vitro dengan Metode Dilusi Tabung dan Dilusi Agar. Daun pepaya merupakan salah satu tanaman yang mengandung zat aktif, terdiri dari asam organic dan fitosterol, alkaloid, saponin, flavonoid, tannin, dan polifenol berfungsi sebagai antimikroba terhadap bakteri, salah satunya adalah Shigella dysenteriae. Tujuan untuk membuktikan efek antimikroba ekstrak etanol daun pepaya terhadap pertumbuhan bakteri Shigella dysenteriae secara in vitro. Penelitian memakai rancangan true experiments dengan menggunakan Post Test Only Control. Konsentrasi ekstrak daun pepaya yang digunakan adalah 5\%,10\%, 15\%, 20\%, 25\%,30\% dan 2 kontrol (kontrol bahan dan kontrol kuman). Analisa data menggunakan one way ANOVA, korelasi, dan regresi. Hasil: Nilai KBM (Kadar Bunuh Minimal) pada konsentrasi 30\%. Hasil uji one way ANOVA menunjukkan adanya perbedaan yang sangat signifikan antar perlakuan $(p=0,004)$. Semakin tinggi konsentrasi ekstrak etanol daun pepaya, semakin besar kemampuan menghambat dan membunuh bakteri Shigella dysenteriae $(\mathrm{r}=-0,472)$. Pemberian konsentrasi ekstrak etanol daun pepaya berpengaruh terhadap penurunan jumlah koloni bakteri Shigella dysenteriae per ml (106) (R2= 22,3\%). Nilai KHM (Kadar Hambat Minimal) pada konsentrasi 10\%. Hasil uji one way ANOVA $(p=0,066)$, pada uji korelasi $(r=-0,564)$ dan pada uji regresi didapatkan (R2 $=31,9 \%)$. Kesimpulan: Ekstrak etanol daun pepaya memiliki efek antimikroba terhadap pertumbuhan koloni Shigella dysenteriae.
\end{abstract}

Kata kunci: Ekstrak etanol daun pepaya, Shigelladysenteriae, KBM, KHM.

\begin{abstract}
The Antimicrobial Effect of Papaya Leaf (Carica papaya L.) Ethanol Extraction to Shigella dysenteriae Growth in-Vitro Using The Agar Dilution And Tube Dilution. Papaya leaf as one of the herbal medicine containing active material such as asam organic dan fitosterol, alkaloid, saponin, flavonoid, tannin, and polifenol that has function as an antimicrobial, one of the bacteria that can be killed is Shigella dysenteriae Research Purpose: To prove the antimicrobial effect of papaya leaf (Carica papaya) extract to the growth of Shigella dysenteriae. This study was using the true experiments design and post test only control. The concentration of papaya leaf extract that used were 5\%,10\%,15\%,20\%,25\%,30\% and 2 controls (material control, and germ control). Analysis of data used one way ANOVA, corellation, and regression. Result: MBC (Minimum Bactericidal Concentration) was the 30\% level. One way ANOVA test showed a significant difference among papaya leaf extract concentration $(p=0,004)$. The bigher concentration of papaya leaf extract, the better its ability to reduce the Shigella dysenteriae burdens $(r=-0,472)$. The concentration of papaya leaf extract affected the decrease of the number of Shigella dysenteriae colonies $(\mathrm{R} 2=22,3 \%)$. MIC (Minimum Inbibitory Concentration) was the $10 \%$ level. One way ANOVA test $(p=0,066)$, corelation test $(r=-0,564)$ and regresi test $(\mathrm{R} 2=31,9 \%)$. Conclusion: Papaya leaf ethanol extraction elicited antimicrobial effect to the growth of Shigella dysenteriae colonies.
\end{abstract}

Key words: Papaya leaf ethanol extraction, Shigella dysenteriae, MBC, MIC

\section{PENDAHULUAN}

Shigellosis merupakan salah satu masalah kesehatan yang ditemukan diseluruh dunia terutama terjadi pada negara berkembang termasukIndonesia. Dinegara maju diperkirakan insiden shigellosis sekitar 0,5-2episode/ orang/tahun sedangkan di negara berkembang lebih dari itu.Shigellosis disebabkan oleh bakteri Shigella sp dan dapat menyebabkanpenyakit disentri yaitu diare akut yang disertai oleh darah dan lendir. Disentri basiler yang berat pada umumnya disebabkan oleh Shigelladysenteriae, akan tetapi dapat juga disebabkan oleh Shigella flexneri,Salmonella dan Enteroinvasive E.coli (EIEC). Penyakit ini menyerang semua golongan umur dengan jumlah penderita baru terbanyak pada golongan umur 1-4 tahun yang jumlahnya mencapai 5.231 orang (Subekti et al, 2001). Survei morbiditas yang dilakukan oleh Subdit Diare, Departemen Kesehatan dari tahun 2000-2010 terlihat 
kecenderunganinsiden naik. Pada tahun 2000 terdapat 301 kasus diare/1000 penduduk,pada tahun 2003 naik menjadi 341/1000 penduduk, tahun 2006 naikmenjadi 423/1000 penduduk dan tahun 2010 menjadi 411/1000 penduduk(Subdit Pengendalian Diare dan Infeksi Saluran Pencernaan Kemenkes RI, 2011). Shigella dysenteriae merupakan bakteri pathogen penyebab shigellosis atau disentri basiler yang merupakan penyakit peradangan akut saluran pencernaan manusia. Gejala klinis dari Shigellosis adalah peradangan usus, diare tiba-tiba disertai nanah, darah dan lendir. Bakteri ini menyebarlewat kontaminasi feses pada makanan dan air, menyebabkan disentri karena toksin Shiga yang dihasilkan. Toksin yang diproduksi dapat menyerang lapisan usus besar, menyebabkan pembengkakan, timbulnya nanah pada dinding usus dan diare berdarah. Gejala lain yang ditimbulkan antara lain kejang perut, demam tinggi, hilangnya nafsu makan, mual, muntah dan nyeri saat buang air besar setelah 1-2 hari terinfeksi bakteriini.

Terapi antibiotik diberikan untuk mempersingkat berlangsungnya penyakit dan penyebaran penyakit (Procop, 2003). Hasil survei pada balita di rumah sakit di Indonesia menunjukkan proporsi Shigella sp sebagai etiologi diare yaitu Shigella dysenteriae 5,9\%; Shigella flexneri 70,6\%; Shigella boydii 5,9\%; Shigella sonnei 17,6\%. Meskipun proporsi Shigellady senteriae rendah tetapi kita harus selalu waspada karena Shigella dysenteriae dapat muncul sebagai KLB (Kejadian Luar Biasa). Lebih berbahaya lagi, KLB ini dapat disebabkan oleh Shigella dysenteriae yang telah resistenterhadap berbagai antibiotik (Sapardiyah dkk, 2004). Pada tahun 2002 di India telah dilaporkan bahwa S. dysenteriae telah resisten terhadap asamnalidixat, siprofloksasin, norfloksasin, ofloksasin dan fluorokuinolon. Padatahun 2004 S. dysenteriae telah mengalami resistensi silang tehadap kloramfenikol, trimetoprim, kuinolon dan tetrasiklin (Uppal and Arora,2004).

Saat ini dengan kembali maraknya gerakan kembali ke alam (backto nature), kecenderungan penggunaan bahan obat alam atau herbal didunia semakin meningkat. Gerakan tersebut dilatarbelakangi perubahan lingkungan, pola hidup manusia, dan perkembangan pola penyakit. Kondisi perekonomian yang terpuruk yang dialami bangsa kita berdampakjuga dengan melonjaknya biaya pengobatan dan harga obat-obatan. Di sisilain, adanya kenyataan bahwa tingkat kebutuhan masyarakat terhadap pengobatan semakin meningkat. Sementara taraf kehidupan sebagian masyarakat kita masih banyak yang kemampuannya paspasan. Maka dariitu, pengobatan tradisional yang ekonomis merupakan solusi yang baik untuk menanggulangi masalah tersebut (Khalid, 2009). Salah satu tanaman tradisional yang diduga dapat digunakan sebagai antimikroba adalah daun pepaya. Penelitian ter dahulumembuktikan bahwa secara in vitro ekstrak daun pepaya memiliki aktivitas antibakteri yang signifikan terhadap bakteri gram positif dangram negative (Anibijuwon, 2009). Berdasarkan penelitian yang telah dilakukan oleh Tadhfirah (2010) ekstrak etanol daun pepaya memilkiaktivitas antibakteri secara in vitro terhadap bakteri Shigella dysenteriae. Semakin besar konsentrasi larutan ekstrak etanol daun pepaya makasemakin sedikit jumlah koloni Shigella dysenteriae yang tumbuh padamedia NAP. Peran itu dimungkinkan oleh kandungan senyawa yangterdapat pada daun pepaya, seperti alkaloid carpaine, asam organik, $\beta$ sitosterol, flavonoid, saponin, tannin, dan polifenol (Masenchipz, 2010). Dalam penelitian ini menggunakan ekstrak daun pepaya denganpelarut etanol dikarenakan sebagian besar zat aktif antimikroba yang terkandung dalam daun pepaya larut dalam etanol. Penelitian terdahulu menggunakan metode dilusi tabung dan Kadar Bunuh Minimum (KBM) saja yang diketahui besarnya tetapi besarnya Kadar Hambat Minimum(KHM) belum diketahui secara pasti dikarenakan sifat larutan yang keruh. Untuk itu dalam penelitian ini peneliti menggunakan dilusi tabung dandilusi agar supaya besarnya Kadar Hambat Minimum (KHM) dan Kadar Bunuh Minimum (KBM) bisa diketahui.Dengan dasar di atas perlu dilakukan penelitian yang bertujuan untuk mengetahui apakah ekstrak etanol daun pepaya memiliki efekantimikroba terhadap koloni Shigella dysenteriae, dengan mengukurKadar Hambat Minimum (KHM) dan mengukur Kadar Bunuh Minimum (KBM).

\section{METODE PENELITIAN}

Penelitian ini memakai rancangan penelitian berupa true eksperimental dengan menggunakan post test only control. Penelitian dilaksanakan di Laboratorium Biomedik Fakultas Kedokteran Universitas Muhammadiyah Malang dan dilakukan pada bulan Februari 2012.

Populasi penelitian berupa bakteri Shigella dysenteriae biakan murni yang diperoleh dari Laboratorium Mikrobiologi Fakultas Kedokteran Universitas Brawijaya Malang. Sampel penelitian bakteri Shigella dysenteriae biakan murni diambil secara simple random sampling. Pengambilan sampel dilakukan dengan bantuan ose yang dimasukkan secara tegak lurus ke dalam wadah kultur bakteri dengan tingkat kedalaman yang sama untuk setiap perlakuan.

Pada penelitian ini menggunakan 8 kelompok, yang terbagi menjadi 6 kelompok perlakuan ekstrak etanol daun pepaya dan 2 kelompok sebagai kontrol.

Variabel bebas pada penelitian ini adalah ekstrak etanol daun pepaya dengan konsentrasi 5\%, 10\%, 15\%, 20\%, 25\%, $30 \%$. Variabel tergantung pada penelitian ini adalah pertumbuhan Shigella dysenteriae dengan mengukur jumlah koloni bakteri Shigella dysenteriae. Penentuan aktivitas antimikroba dilakukan dengan 2 metode dilusi yaitu dilusi tabung dan dilusi agar.

Dilusi tabung dikerjakan dengan menggunakan satu seri tabung reaksiyang diisi media cair dan sejumlah tertentu sel mikroba yang diuji.Kemudian masingmasing tabung diisi dengan antimokroba yang telahdiencerkan secara serial. Selanjutnya, seri tabung diinkubasikan pada suhu $37^{\circ} \mathrm{C}$ selama $18-24$ jam dan diamati terjadinya kekeruhan pada tabung.Konsentrasi terendah antimikroba pada tabung yang ditunjukkan denganhasil biakan yang mulai tampak jernih (tidak ada pertumbuhan mikroba)adalah Kadar Hambat Minimal (KHM) dari antimikroba. Untukmenentukan KHM bahan uji, dapat juga menggunakan médium agar padatyang disebut dengan metode E test. Selanjutnya biakan dari semua tabung yang jernih diinokulasikan pada media agar padat (streaking 
satu osebakteri dari masing-masing konsentrasi ke plateplate yang berbeda), diinkubasikan dan keesokan harinya diamati ada tidaknya koloni mikroba yang tumbuh. Konsentrasi terendah antimikroba pada biakan padat yangditunjukkan dengan tidak adanya pertumbuhan koloni mikroba adalah Kadar Bunuh Minimal (KBM) dari bahan uji terhadap bakteri uji. Bahanuji seringkali tidak dapat memubunuh secara total sekuruh populasi bakteri, sehingga KBM merupakan kadar terendah yang memungkinkanpertumbuhan bakteri uji hanya $<0,1 \%$ dari jumlah bakteri uji yang diinokulasikan. Jumlah bakteri yang diinokulasikan adalah setara dengan jumlah koloni yang ditemui pada subkultur kontrol bakteri pada NutrientAgar Plate (NAP) segera setelah suspensi inokulum terbentuk (Dzen, 2003).

Dilusi agar digunakan bila dengan menggunakan tubedilution tidak dapat dilihat KHM nya, yaitu menggunakan cara agar dilution. Pada metode ini, bahan antimikroba dengan konsentrasitertentu dicampur dengan agar plate, satu plate untuk satu konsentrasi yang ingin diuji. Bakteri yang akan diujikan dibuat dengan turbiditas sedikit lebih besar dari standard spectrofotometry. Kemudian sejumlah bakteri diletakkan pada sebuah replicating inoculator (yang dinamakan Steers-Folts replicator) yang sudah dikalibrasi (biasanya0,001ml). Setelah itu suspensi bakteri tersebut diletakkan pada permukan agar. Pada cara ini ada sekitar 104CFU pada permukaanagar plate. Kemudian agar plate diinkubasi. Konsentrasi terendah yang menampakkan pertumbuhan koloni kurang dari 3 disebut sebagai kadar hambat mínimum (KHM). Kadar bunuh minial (KBM) tidak dapat dilihat pada metode ini (Dzen, 2003).

\section{HASIL PENELITIAN}

Sebelum digunakan dalam penelitian ini, sampel bakteri diidentifikasi ulang. Identifikasi dilakukan dengan cara melakukan pewarnaan gram dengan hasil batang gram negatif (ditandai dengan warna merah), tesbiokimia, yang terdiri dari tes IMViC (Indole, Methyl red, VogesProskaner,Citrate test), tes motilitas, dan tes urease. Hasil tes biokimia Shigellady senteriae dengan hasil: Motilitas (), Urease (-), Indole (+), Methyl $\operatorname{red}(+)$, Citrate (-), dan Voges Proskauer (-).Prosedur dari metode dilusi tabung adalah untuk menentukan KadarHambat Minimal (KHM) dan Kadar Bunuh Minimal (KBM), namun padapenelitian ini nilai KHM tidak dapat dianalisis, karena tingkat kekeruhannyabukan menunjukkan adanya pertambahan jumlah koloni bakteri, melainkanwarna asli dari ekstrak yang keruh, sehingga yang dinilai hanya KBM Kadar Bunuh Minimal (KBM) ditentukan jika didapatkan penurunanjumlah koloni bakteri $<0,1 \%$ dari inokulum asal. Hasil pertumbuhan koloni bakteri. Untuk memudahkan penghitungan danmemperkecil kesalahan hitung jumlah koloni maka digunakan colony counter. Hasil dari perhitungan rata-ratajumlah koloni Shigella dysenteriae per cawan dalam beberapa konsentrasiekstrak etanol daun papaya (Carica papaya L.) dapat dilihat pada tabel 1.

Dari tabel 1 terlihat bahwa terjadi penurunan jumlah rata-rata koloni bakteri Shigella dysenteriae seiring dengan peningkatan konsentrasi ekstrak etanol daun pepaya. Pada penelitian ini Kadar Bunuh Minimal (KBM) ekstrak etanol daun pepaya terhadap koloni Shigellady senteriae, ditetapkan pada konsentrasi 30\%.

Sedangkan hasil perhitungan rata-rata jumlah koloni Shigellady senteriae per 0,2ml (106) dalam beberapa konsentrasi ekstrak etanol daunpapaya (Carica papaya L.) dapat dilihat pada tabel 2 .

Dari tabel 2 dapat dilihat bahwa rata-rata jumlah koloni bakteri Shigellady senteriae per 0,2ml (106) yang dihasilkan pada agar SS berbedatiap kelompok perlakuan. Jumlah rata-rata koloni Shigella dysenteriae per0,2ml (106) terus menurun seiring dengan peningkatan konsentrasi ekstraketanol daun pepaya.

Untuk menganalisis perbedaan bermakna terhadap pengaruh beberapa konsentrasi ekstrak etano daun pepaya dalam menghambat pertumbuhanShigella dysenteriae per 0,2ml (106) dilakukan uji One Way ANOVA, dimana syaratnya adalah distribusi data harus normal dan varians data harus sama. Pada Uji normalitas, didapatkan nilai $\mathrm{p}=0,181$. Karena nilai $\mathrm{p}>0,05$, maka dapat disimpulkan bahwa distribusi datanormal

Pada Test of homogenity, terlihat bahwa nilai signifikansi $(\mathrm{p})=0.076$. Karena nilai $\mathrm{p}>0,05$ maka dapat diambil kesimpulan bahwatidak ada perbedaan karakteristik antar kelompok data yang dibandingkan dengan kata lain varians data adalah homogen. Karena varians data sama,maka uji One way ANOVA adalah valid. Pada uji One way ANOVA diperoleh $\mathrm{p}=0.004$, karena $\mathrm{p}<1 \%$ maka dapat disimpulkan bahwa terdapat perbedaan yang sangat signifikan pada jumlah koloni bakteri Shigella dysenteriae per $0,2 \mathrm{ml}$ (106) akibat pengaruh perlakuan padaberbagai macam konsentrasi ekstrak etanol daun pepaya yang dilakukan.

Untuk mengetahui konsentrasi ekstrak etanol daun pepaya mana saja yang berbeda secara signifikan dengan yang tidak signifikan pengaruhnya terhadap pertumbuhan koloni Shigella dysenteriae, maka dilakukan uji Post-Hoc test sebagai uji lanjutan dari One way ANOVA. Dengan hasil pengujian seperti pada lampiran 4. Pada uji Post-Hoc test, jika nilai $\mathrm{p}>0,05$ maka variabel tidak signifikan. Pada perbandingan jumlah koloni bakteri Shigellady senteriae per 0,2ml (106) yang dihasilkan pada agar SS antar kelompok kontrol negatif dengan berbagai macam konsentrasi ekstrak etanol daunpepaya menunjukkan perbedaan yang signifikan.

Plot respon dari pengaruh perlakuan berbagai macam konsentrasi ekstrak etanol dau pepaya terhadap jumlah koloni bakteri Shigella dysenteriae per 0,2ml (106), dapat ditunjukkan pada gambar 1. 
Tabel 1 Jumlah koloni rata-rata Shigella dysenteriae per cawan dalam beberapa konsentrasi ekstrak etanol daun papaya (Carica papaya L.) pada dilusi tabung

\begin{tabular}{cccccc}
\hline \multicolumn{3}{c}{ Ulangan } & & & Rata-rata bakteri \\
\cline { 1 - 3 } 1 & 2 & 3 & & bakteri & \\
\hline 8631 & 5013 & 7770 & & 21414 & 7138 \\
6498 & 9557 & 0 & & 16055 & 5352 \\
0 & 4895 & 1885 & 6780 & 2260 \\
528 & 197 & 2905 & 3630 & 1210 \\
490 & 1057 & 257 & 1804 & 601 \\
0 & 39 & 6 & 45 & 15 \\
6 & 0 & 0 & 6 & 2 \\
0 & 0 & 0 & 0 & 0
\end{tabular}

Tabel 2 Jumlah koloni Shigella dysenteriae per $0,2 \mathrm{ml}$ (106) dalam beberapa konsentrasi ekstrak etanol daun papaya (Carica papaya L.) padadilusi tabung

\begin{tabular}{|c|c|c|c|c|}
\hline \multicolumn{3}{|c|}{ Ulangan } & \multirow[b]{2}{*}{ bakteri } & \multirow[t]{2}{*}{ Rata-rata bakteri } \\
\hline 1 & 2 & 3 & & \\
\hline 3,331 & 1,935 & 2,999 & 8,265 & 2,755 \\
\hline 2,508 & 3,689 & 0 & 6,197 & 2,066 \\
\hline 0 & 1,890 & 0,728 & 2,618 & 0,873 \\
\hline 0,204 & 0,076 & 1,121 & 1,401 & 0,467 \\
\hline 0,189 & 0,408 & 0,099 & 0,696 & 0,232 \\
\hline 0 & 0,015 & 0,002 & 0,017 & 0,006 \\
\hline 0,002 & 0 & 0 & 0,002 & 0,001 \\
\hline 0 & 0 & 0 & 0 & 0 \\
\hline
\end{tabular}

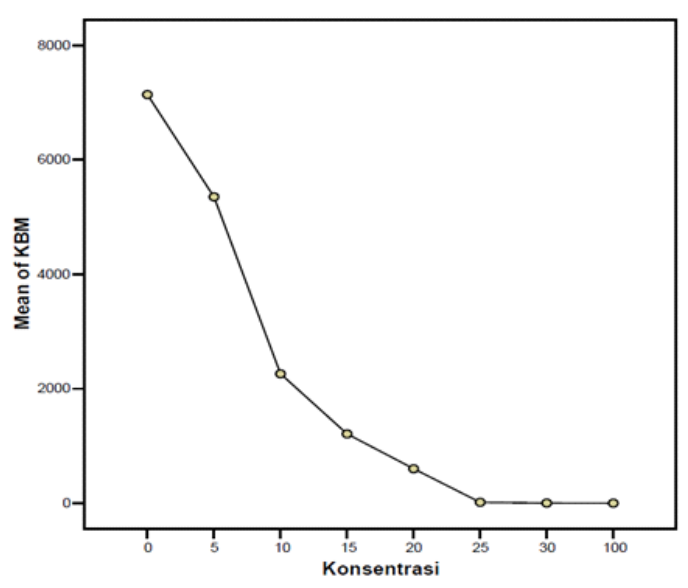

Gambar 1. Plot respon pengaruh perlakuan dari variasi konsentrasi ekstrak etanol daun pepaya terhadap jumlah koloni bakteri Shigella dysenteriaeper 0,2ml (106) pada dilusi tabung.

Plot respon di atas menunjukkan besarnya pengaruh perlakuan berbagai macam konsentrasi ekstrak etanol daun pepaya terhadap jumlah koloni bakteri Shigella dysenteriae per $0,2 \mathrm{ml}$ (106). Berdasarkan plot respontersebut dapat dibentuk urutan dari perlakuan konsentrasi ekstrak etanol.

Daun pepaya dengan rata-rata jumlah koloni bakteri Shigella dysenteriae per $0,2 \mathrm{ml}$ (106) yang dihasilkan pada agar SS dari urutan rata-rata terbanyakhingga rata-rata jumlah koloni bakteri Shigella dysenteriae yang palingsedikit.
Pada konsentrasi 0\% menunjukkan jumlah koloni bakteri Shigella dysenteriae terbanyak, sedangkan konsentrasi 25\%, $30 \%, \quad 100 \%$ sudah terlihat penurunan koloni bakteri Shigella dysenteriae yang semakin drastis.

Besarnya hubungan dan pengaruh dari beberapa konsentrasi ekstraketanol daun pepaya dengan jumlah Shigella dysenteriae per $0,2 \mathrm{ml}$ (106), maka dilakukan uji korelasi dan uji regresi linier. Nilai kolerasi dari konsentrasi ekstrak etanol daun pepaya dengan jumlah koloni bakteri per0,2ml (106) sebesar -0,472 dengan nilai signifikansi $(p=0,000<0,01)$, hal inimenunjukkan kolerasi yang terjadi adalah kolerasi berbanding terbalik, yangartinya kenaikan konsentrasi ekstrak etanol daun pepaya menyebabkan penurunan jumlah koloni per 0,2ml (106).

Analisis regresi linier dilakukan untuk mengetahui seberapa besarpengaruh berbagai macam konsentrasi ekstrak etanol daun pepaya terhadap koloni Shigella dysenteriae per 0,2ml (106). Berdasarkan uji regresi linier, nilai koefisien determinasi ( $\mathrm{R}$ Square $=\mathrm{R} 2$ ) untuk jumlah koloni per 0,2ml(106) sebesar 22,3\%. Artinya bahwa 22,3\% jumlah koloni Shigellady senteriae dipengaruhi oleh ekstrak etanol daun pepaya. Sedangkan sisanya yaitu 77,7\% dipengaruhi oleh faktor lain yang tidak dibahas pada penelitianini, seperti kandungan senyawa antimikroba, suhu, $\mathrm{pH}$ lingkungan, ataumateri organik.

Prosedur dari metode dilusi agar adalah untuk menentukan KadarHambat Minimal (KHM). Kadar Hambat Minimal (KHM) ditentukan jika didapatkan pertumbuhan bakteri kurang dari 3 pada media dilusi agar. Hasil pertumbuhan koloni bakteri Shigella dysenteriae pada 
media dilusi agar tiap konsentrasi ekstrak daun pepaya dapat dilihat pada lampiran 3. Hasil dari perhitungan rata-rata jumlah koloni Shigella dysenteriae per plate dalambeberapa konsentrasi ekstrak etanol daun papaya (Carica papaya L.) dapat dilihat pada tabel 3 .

Dari tabel 3 terlihat bahwa terjadi penurunan jumlah rata-rata koloni bakteri Shigella dysenteriae seiring dengan peningkatan konsentrasi ekstrak etanol daun pepaya. Pada penelitian ini Kadar Hambat Minimal (KHM) ekstrak etanol daun pepaya terhadap koloni Shigellady senteriae, ditetapkan pada konsentrasi 10\%. Untuk menganalisis perbedaan bermakna terhadap pengaruh beberapa konsentrasi ekstrak etanol daun pepaya dalam menghambat pertumbuhan Shigella dysenteriae per 10 $\mu$ l (104) dilakukan uji One Way ANOVA, dimana syaratnya adalah distribusi data harus normal dan varians data harus sama.

Pada bagian Uji normalitas pada lampiran 4, didapatkan nilai $\mathrm{p}=0$,983.Karena nilai $\mathrm{p}>0,05$, maka dapat disimpulkan bahwa distribusi data normal.

Pada test of homogenity pada terlihat bahwa nilai signifikansi $(\mathrm{p})=0.058$. Karena nilai $\mathrm{p}>0,05$ maka dapat diambil kesimpulan bahwa tidak ada perbedaan karakteristik antar kelompok data yang dibandingkan dengan kata lain varians data adalah homogen. Karena varians data sama, maka uji One way ANOVA adalah valid. Pada uji One way ANOVA diperoleh $\mathrm{p}=0.066$, karena $\mathrm{p}<1 \%$ maka dapat disimpulkan terdapat perbedaan yang sangat signifikan pada jumlah koloni bakteri Shigellady senteriae per $10 \mu \mathrm{l}$ (104) akibat pengaruh perlakuan pada berbagai macam konsentrasi ekstrak etanol daun pepaya yang dilakukan.

Untuk mengetahui konsentrasi ekstrak etanol daun pepaya mana saja yang berbeda secara signifikan dengan yang tidak signifikan pengaruhnya terhadap pertumbuhan koloni Shigella dysenteriae, maka dilakukan uji PostHoc test sebagai uji lanjutan dari One way ANOVA. Pada uji Post-Hoc test, jika nilai $\mathrm{p}>0,05$ maka variabel tidak signifikan. Pada perbandingan jumlah koloni bakteri Shigellady senteriae per 10 $\mu$ l (104) yang dihasilkan pada agar SS antar kelompok kontrol negatif dengan berbagai macam konsentrasi ekstrak etanol daun pepaya menunjukkan perbedaan yang signifikan.

Plot respon dari pengaruh perlakuan berbagai macam konsentrasi ekstrak etanol daun pepaya terhadap jumlah koloni bakteri Shigella dysenteriae per 10 $\mu$ l (104), dapat ditunjukkan pada gambar 2.

Plot responpada gambar 2 menunjukkan besarnya pengaruh perlakuan berbagai macam konsentrasi ekstrak etanol daun pepaya terhadap jumlah koloni bakteri Shigella dysenteriae per $10 \mu \mathrm{l}(104)$. Berdasarkan plot respon tersebut dapat dibentuk urutan dari perlakuan konsentrasi ekstrak etanoldaun pepaya dengan rata-rata jumlah koloni bakteri Shigella dysenteriae per10 $\mu$ l (104) yang dihasilkan pada agar SS dari urutan rata-rata terbanyak hingga ratarata jumlah koloni bakteri Shigella dysenteriae yang paling sedikit.

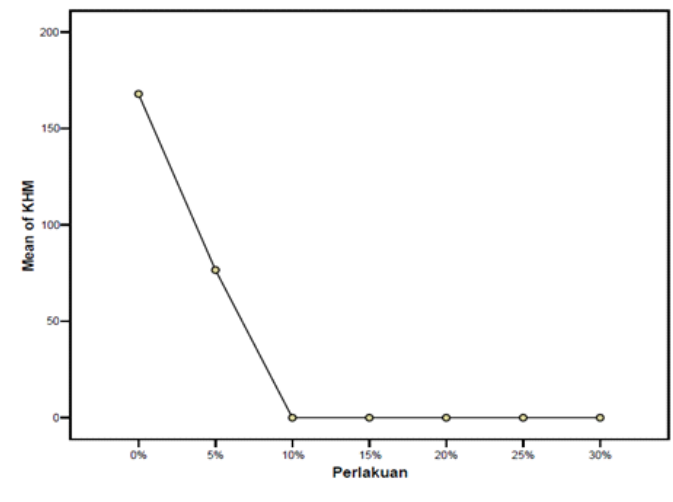

Gambar 5.2. Plot respon pengaruh perlakuan dari variasi konsentrasi ekstrak etanol daun pepaya terhadap jumlah koloni bakteri Shigella dysenteriaeper 10 $\mu$ l (104) pada dilusi agar

Pada konsentrasi 0\% menunjukkan jumlah koloni bakteri Shigelladysenteriae terbanyak, sedangkan konsentrasi $10 \%, 15 \%, 20 \%, 25 \%, 30 \%$ sudah terlihat penurunan koloni bakteri Shigella dysenteriae yang semakindrastis.

Besarnya hubungan dan pengaruh dari beberapa konsentrasi ekstraketanol daun pepaya dengan jumlah Shigella dysenteriae per 10 $\mu$ (104),maka dilakukan uji korelasi dan uji regresi linier. Nilai kolerasi darikonsentrasi ekstrak etanol daun pepaya dengan jumlah koloni bakteri per10 $\mu$ l (104) sebesar -0,564 dengan nilai signifikansi $(p=0,000<0,01)$, hal inimenunjukkan kolerasi yang terjadi adalah kolerasi berbanding terbalik, yang artinya kenaikan konsentrasi ekstrak etanol daun pepaya

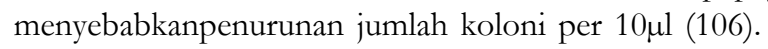

Analisis regresi linier dilakukan untuk mengetahui seberapa besarpengaruh berbagai macam konsentrasi ekstrak etanol daun pepaya terhadap koloni Shigella dysenteriae per $10 \mu \mathrm{l}$ (104). Berdasarkan uji regresi linier,nilai koefisien determinasi (R Square=R2) untuk jumlah koloni per $10 \mu \mathrm{l}(104)$ sebesar 31,9\%. Artinya bahwa 31,9\% jumlah koloni Shigellady senteriae dipengaruhi oleh ekstrak etanol daun pepaya. Sedangkan sisanya yaitu $68,1 \%$ dipengaruhi oleh faktor lain yang tidak dibahas pada penelitianini, seperti kandungan senyawa antimikroba, suhu, $\mathrm{pH}$ lingkungan, ataumateri organik.

\section{PEMBAHASAN}

Penelitian ini dilakukan untuk mengetahui efek antimikroba ekstrak etanoldaun pepaya (Carica papaya L.) terhadap bakteri Shigella dysenteriae. Rancangan penelitian yang digunakan adalah true eksperimental dengan menggunakan Post test only control.

Berdasarkan penelitian yang telah dilakukan, Kadar Bunuh Minimum (KBM)didapatkan pada konsentrasi 30\% dan nilai R2 sebesar 22,3\%. KBM ditentukan jikapada cawan didapatkan penurunan jumlah koloni bakteri sampai $<0,1 \%$ dari original inoculum dengan menggunakan dilusi tabung. Pada tabel 5.1 dan 5.2pengulangan konsentrasi $5 \%, 10 \%$ menunjukkan selisih perbedaan jumlah kolonibakteri Shigella dysenteriae yang sangat 
signifikan, hal ini disebabkan oleh kekurangan dari penelitian ini yaitu pada saat pengambilan satu mata ose darisuspensi bakteri dalam broth tidak sama pada tiap pengulangan sehingga menyebabkan jumlah koloni bakteri tiap pengulangan pada konsentrasi tertentu ada perbedaan yang sangat signifikan. Pada dilusi tabung Kadar Hambat Minimum (KHM) tidak dapat diketahui dikarenakan warna larutan ekstrak daun pepaya yangkeruh. Untuk itu selain dilakukan dilusi tabung dilakukan juga penelitian dengan menggunakan dilusi agar sehingga KHM dapat diketahui. Pada dilusi agar KHM didapatkan pada konsentrasi 10\% dan nilai R2 sebesar 31,9\%. KHM ditentukan jikapada plate didapatkan $<3$ koloni bakteri.

Hasil penelitian ini sesuai dengan teori mengenai berbagai macam faktoryang mempengaruhi pertumbuhan bakteri, salah satu contohnya adalah konsentrasizat antimikroba, di mana pada umumnya semakin tinggi konsentrasi suatu zat, makasemakin tinggi pula daya antimikrobanya (Dzen, 2003).

Perbedaan rentang nilai antara KBM dan KHM cukup jauh, hal inidikarenakan pada perbedaan teknik kedua metode. Pada dilusi tabung untuk mencarinilai KBM penghitungan bakteri dilakukan pada hari ke-3, setelah bakteri disuspensikan pada SS broth lalu diinkubasikan selama 18-24 jam pada suhu $37^{\circ} \mathrm{Ckemudian} \mathrm{di} \mathrm{streaking}$ pada media SS plate diinkubasikan lagi dan keesokan harinyabakteri dihitung dengan colony counter. Sedangkan pada dilusi agar untuk mencari nilai KHM penghitungan bakteri dilakukan pada hari ke-2, setelah bakteri diteteskan pada media dilusi agar diinkubasikan selama 18-24 jam pada suhu $37^{\circ} \mathrm{C}$ lalu dihitung jumlah koloni bakteri. Hal inilah yang menyebabkan perbedaaan nilai $\mathrm{KBM}$ dan KHM yang sangat signifikan karena semakin lama waktu diinkubasikan semakinbanyak pula jumlah koloni bakteri Shigella dysenteriae yang tumbuh.

Pada penelitian ini, menggunakan zat kimia berupa etanol sebagai pelarutekstrak, tetapi kemungkinan zat kimia ini tidak berpengaruh pada efek antimikroba yang terjadi, karena ekstrak etanol telah mengalami proses evaporasi. Sedangkan suhu, kemungkinannya sebagai faktor yang berpengaruh sangat kecil, karena suhu inkubator telah diatur sesuai dengan habitat pertumbuhan bakteri. Jadi kemungkinan faktor lain yang berpengaruh adalah $\mathrm{pH}$ lingkungan, materi organik dan senyawa antimikroba. Beberapa bakteri dapat melakukan penguraian materi organik secara anaerob, dengan cara menghidrolisa komponen organik kompleks menjadi komponen organik sederhana. Selain itu, kerja anti bakteri juga memerlukan $\mathrm{pH}$ tertentu, namun pada umumnya bakteri memiliki jarak $\mathrm{pH}$ yang sempit (Dzen, 2003).

Penelitian terdahulu membuktikan bahwa secara in vitro dengan metode difusi agar ekstrak daun pepaya memiliki aktivitas antibakteri yang signifikan terhadap bakteri gram positif dan gram negative. Bakteri yang digunakan pada penelitian ini meliputi bakteri Escherichia coli, Pseudomonas aeruginosa, Klebseilla pneumonia, Staphylococcus aureus, Proteus mirabilis. Pada penelitian ini aktivitas telah didapatkan bahwa ekstrak daun pepaya memilki aktivitas menghambat bakteri lebih tinggi pada bakteri gram negatif dibanding gram positif. Aktivitas ekstrak daun pepaya tertinggi didapatkan pada bakteri Pseudomonas aeruginosa yaitu dengan zonainhibisi sebesar 4,2 mm (Anibijuwon,2009).

Penelitian lain membuktikan bahwa secara in vitro ekstrak etanol daun pepaya memiliki aktivitas antibakteri yang signifikan terhadap Shigella dysenteriae, dengan nilai KBM sebesar $10 \%$ dan nilai regresi R2 sebesar 87,8\%. Peneliti menggunakan metode dilusi tabung sehingga hanya KBM yang dapat diketahui dan KHM tidak dapat diketahui dikarenakan warna ekstrak yang keruh (Tadhfirah, 2010). Perbedaan hasil nilai KBM dan nilai regresi R2 yang sangat signifikan antara penelitian ini dengan penelitian yang dilakukan oleh Tadhfirah dikarenakan beberapa perbedaan pada teknik penelitian. Pada penelitian Tadhfirah media yang digunakan adalah NAP sedangkan pada penelitian ini menggunakan media selektif yaitu media agar Salmonella-Shigella (SS), dimana media agar SS adalah media yang baik untuk pertumbuhan bakteri Shigella dysenteriae. Pelarut etanol dalam ekstrak daun pepaya juga dapat membunuh bakteri Shigella dysenteriae, jika dalam ekstrak pelarut etanol belum menguap secara keseluruhan akan membunuh bakteri. Hal ini dapat menyebabkan perbedaan nilai KBM dan regresi R2 yang sangat signifikan.

Hasil penelitian di atas membuktikan bahwa ekstrak etanol daun pepaya dapat berfungsi sebagai anti mikroba terhadap Shigella dysenteriae. Hal ini diduga karena ekstrak etanol daun pepaya mengandung berbagai senyawa yang berpotensi sebagai anti mikroba, yaitu alkaloid carpaine, asam organik, $\beta$ sitosterol, flavonoid, saponin, tannin, dan polifenol (Masenchipz, 2010).

Salah satu zat antimikroba yang paling banyak terkandung dalam daun pepaya adalah alkaloid. Mekanisme kerja dari alkaloid dalam membunuh bakteri adalah dengan kemampuan mereka untuk berinterkalasi dengan asam deoksiribosa nukleat (DNA) bakteri yaitu dengan meletakkan diri di antara untaian DNA (Cowan, 1999).

Perubahan susunan rantai asam amino ini jelas akan mempengaruhi keseimbangan genetic pada DNA yang berlanjut pada kerusakan DNA. Kerusakan DNA tentunyajuga akan menyebabkan rusaknya inti sel, sehingga inti sel akan lisis. Lisisnya inti sel bakteri akan menyebabkan juga kerusakan sel pada bakteri karena inti sel merupakan pusat kegiatan sel. Kerusakan sel pada bakteri ini lama kelamaan akan membuat sel-sel bakteri tidak mampu melakukan metabolisme sehingga juga akan mengalami lisis.

Dengan demikian bakteri akan menjadi inaktif dan hancur (Gunawan, 2009).

\section{KESIMPULAN}

Dari penelitian yang dilakukan, didapatkan kesimpulan bahwa KBM ekstrak etanol daun papaya ditentukan pada konsentrasi 30\%. Ekstrak etanol daun papaya mempunyai daya antimikroba terhadap pertumbuhan koloni bakteri Shigella dysenteriae. KHM ekstrak etanol daun papaya ditentukan pada konsentrasi 10\%. Semakin tinggi konsentrasi ekstrak etanol daun pepaya menyebabkan semakin sedikit pertumbuhan bakteri Shigella dysenteriae. Sebaliknya, semakin rendah konsentrasi ekstrak etanol daun papaya menyebabkan semakin meningkatnya jumlah koloni bakteri Shigella dysenteriae yang tumbuh pada SSP. 


\section{DAFTAR PUSTAKA}

Adam, 2001, Shigella dysenteriae, diakses 10 Juni 2011, (http:/ /www.adam.com).

Anibijuwon, 2009, Antimicrobial Activity of Carica Papaya (pawpaw leaf) on Some Pathogenic Organisms of Clinical Origin from South-Western Nigeria, Nigeria: Departement of Microbiology University of Ilorin.

Ardiansyah, 2005, Antimikroba dari Tumbuhan, diakses pada 24 Maret 2011, (http://www.beritaiptek.com/ zberita-beritaiptek-2007-06-09).

Ardina Y, 2007, Pengembangan Formulasi Sediaan Gel Antijerawat serta Penentuan Konsentrasi Hambat Minimum Ekstrak Daun Pepaya, diakses 15

Oktober 2011, (http://digilib.itb.ac.id/gdl.php? $\bmod =$ browse\&node $=6489$ ).

Balai Besar Pelatihan Pertanian Lembang, 2010, Budidaya Pepaya, diakses 21 Maret 2011, (http:// www.bbplembang.com).

Bonang G, 1982, Mikrobiologi Kedokteran: Untuk Laboratorium dan klinik. Jakarta: Gramedia, Hal: 1015.

Bukhori M.F.M, Rahman N.A, et al, 2005, Carpaine from Carica Papaya L. Var Eksotika I, Prosiding Simposium Kimia Analisis Malaysia Kelapan Belas, Johor Bahru.

Cowan, 1999, Plant Produk as antimicrobial agents Clinical Microbiology Reviews, California: Addison Wesley Longman Inc. hal 565-582.

Clark J, 2007, Pembuatan Ester, diakses 20 Mei 2011, (http://www.chem-is-try.org/materi kimia/ sifat_senyawa_organik/ ester1/pembuatan_ester/).

Dall A.R, Ferraz A, Bernardi A.P, et al, 2003, Antimicrobial Activity of Some Hypericum species, Brazil: TANAC SA, Hal: 511-516.

Davidson M.W, 2004, Saponin, diakses pada tanggal 24 Maret 2011, (http://micro.magnet.fsu.edu/ phytochemicals/pages/saponin.html).

Doughari J.H, Elmahmood A.M, \& Manzara S, 2007, Studies on the Antibacterial activity of Root Extracts of Carica Papaya L, diakses 15 Juni 2011, (http://www.academicjournals.org/ajmr).

Dzen, Sjoekoer M, Roekistiningsih, et al, 2003, Bakteriologi Medik, Malang: Bayumedia, Hal: 122187.

Dzen, Sjoekoer M, Roekistiningsih, et al, 2005, Petunjuk Praktikum Mikrobiologi Kedokteran, Malang: Laboratorium Mikrobiologi Fakultas Kedokteran Universitas Brawijaya, Hal: 17, 24-27, 43-44.

Farlex, 2010, Fight Cancer With the Part of This Tropical Plant That's Thrown Away, telah diakses pada tanggal 10 Oktober 2011, (http://www. academicjournals. faqs.org/patents/app/20090310839+Nan+Dang, + journal, +carica+papaya $+\mathrm{L} \& \mathrm{~cd}=9 \& \mathrm{hl}=\mathrm{i} \mathrm{d} \& \mathrm{ct}=$ clnk\&gl=id\&client=firefox-a).

Florakita, 2008, Carica Papaya, telah diakses pada tanggal 20 Juni 2011, (http://www.proseanet. org/florakita).

Gunawan I. W. A, 2009, Potensi Buah Pare (Momordica Charantia L) Sebagai Antibakteri Salmonella typhimurium, Denpasar: Program Studi Pendidikan Biologi Fakultas Keguruan dan Ilmu Pendidikan Universitas Mahasaraswati.
Hismiogullari, Sahin, Karasartova, et al, 2008, Investigation of Antibacterial andCytotoxic Effects of Organic Acids Including Ascorbic Acid, Lactic Acid,and Acetic Acid on Mammalian Cells, Journal of Animal and Veterinary Advances 7 (6): 681-684.

Jawetz E, Melnick J.L \& Adelberg E.A, 2001, Mikrobiologi Kedokteran (Medical Microbiology), Jakarta: Salemba Medika, Hal: 347-350

Jawetz E, Melnick J.L, \& Adelberg E.A, 2004, Mikrobiologi Kedokteran (MedicalMicrobiology) edisi 20, Jakarta: EGC, Hal: 259-260

Jawetz E, Melnick J.L, \& Adelberg E.A, 2005, Mikrobiologi Kedokteran (Medical Microbiology) edisi 22, Jakarta: Salemba Medika, Hal: 362-364.

Katzung, Bertram G, 1994, Farmakologi Dasar dan Klinik, Jakarta: EGC,Hal: 699.

Khalid, 2009, Khasiat Daun Pepaya, telah diakses pada tanggal 20 Maret 2011,(http://www.carahidup. um.ac.id).

Laily N, 2009, Mikrobia Patogen, telah diakses pada tanggal 25 Juni 2011,(http://dinkes. kulonprogokab. go.id).

Masenchipz, 2010, Khasiat Pepaya Untuk Wanita, diakses 10 Januari 2011,(http://www.masenchipz. com).

Nuri M.S, \& Puspitasari E, 2008, Buku Petunjuk Praktikum Fitokimia. EdisiRevisi III, Jember: Bagian Biologi Farmasi Program Studi FarmasiUniversitas Jember.

Procop G.W \& Cockerill F.V, 2003, Current Diagnosis and Treatment inInfectious Disease, New York: Lange Medical Books, Hal: 13-603.

Robinson T, 1995, Kandungan Organik Tumbuhan Tinggi, Terjemahan oleh Prof. Dr. Kosasih Padmawinata FMIPA ITB, Bandung: ITB, Hal. 4, 71 72,191-202.

Ross, 2006, Enteric Demonstrations; Medical Microbiology; USA, diakses 10September 2011, (www.spiceisle.com/ zross/Enteric\%20Demo.html).

Rukmana R, 1994, Pepaya Budidaya dan Pascapanen, Yogyakarta : Kanisius.

Sabri Luknis, 2006, Statistik Kesehatan, Rajagrafindo, Jakarta, pp. 12-14.

Sastroasmoro Sudigdo, 2005, Dasar-Dasar Metodologi Penelitian Klinis, Jakarta: Binarupa Aksara.

Shuid A.N, Anwar M.S, Yusof A.A, 2005, The Effects of Carica papaya Linn, Latex on the healing of Burn Wounds in Rats, Jurnal Sains Kesihatan Malaysia 3 (2): 39- 47.

Subdit Pengendalian Diare dan Infeksi Saluran Pencernaan Kemenkes RI, 2011, Situasi Diare di Indonesia, diakses tanggal 8 februari 2012,(www.depkes.go.id/ downloads/Buletin\%20Diare_Final(1).pdf).

Subekti D, et al, 2001, Shigella spp. Surveillance in Indonesia: the Emergence or Reemergence of $S$. Dysenteriae, telah diakses pada tanggal 10 Juni 2011, (http:// as.medscape.com).

Tadhfirah F, 2010, Pengaruh Ekstrak Daun Pepaya (Carica papaya L.) terhadap Pertumbuhan Shigella dysenteriae secara In Vitro, Skripsi Universitas Brawijaya, Malang. 
Uppal B, Arora VM, 2004, India Changing resistence pattern Shigella of isolates in a Delbi hospital: An alarming trend, Department of Microbiology,Maulana Azad Medical College and Associated LN Hospital, New Delhi, diakses 10Juni 2011, (http://www.cria.org.br/sp/ index?en+Shigella+dysenteriae).

Zpravy, 2006, Resistance to Clindamycin, diakses pada tanggal 21 Maret 2011, (http://www.szu.cz/cem/zpravy/ zpr0306? klinda.htm). 